https://doi.org/10.18485/bogoljub_stankovic.2018.ch3

811.161.1'34

\author{
ЈЕЛЕНА ГИНИЋ* \\ Универзитет у Београду \\ Филолошки факулет \\ Катедра за славистику
}

\title{
АКЦЕНТУАЦИЈА РУСКОГ И СРПСКОГ ЈЕЗИКА У КОНТРАСТУ
}

\begin{abstract}
Дати рад представља покушај контрастирања руског и српског акцентуацијског система (с акцентом на акцентуацијском систему руског језика у поређењу са српским). У раду се разматрају, поред акцента као прозодијског (супрасегментног) средства, и прозодијске (супрасегментне) јединице руског и српског језика у контрасту: акцентовани и редуковани вокалски гласови.
\end{abstract}

Кљуине речи: акценат, вокалски глас, квантитативно-квалитативни акценат, музички акценат, једнородност, неједнородност, редукција, место акцента

Jelena Ginic

\section{CONTRASTIVE ANALYSIS OF ACCENTUATION IN RUSSIAN AND SERBIAN}

This paper represents an attempt to contrast the Russian and Serbian accentuation systems (with emphasis on the accentuation system of the Russian language in comparison with Serbian). In the paper are being considered suprasegmentary units of the Russian and Serbian languages in contrast: accentuated and reduced vowels.

Key words: accent, vowels, qualitative-quantitative word stress, pitch accent, homogeneity/heterogeneity of stressed vowels, reduction, accent place

*jelena.ginic@fil.bg.ac.rs 


\section{„Акцент - ударение”}

Сам термин „акценат” (имамо у виду лексички акценат, тј. акценат речи) је данас у лингвистици вишезначан из најмање два разлога ${ }^{1}$.

Први разлог за вишезначност илустрована је дихотомијом „акцент - ударение": у савременој, можда пре западној лингвистичкој литератури, разликују се два појма за акценат. У англо-америчкој лингвистици то су термини „stress” и „асcent”, а у савременој руској - „акцент” и „ударение”. Енглески термин „stress” односи се на апстрактну категорију, истицање у оквиру речи постоји у говорниковом менталном лексикону, док термин „accent” представља конкретну реализицају истицања једног слога у говору (Gut et al. 2006: 6). Дати термини су у употреби у руској лингвистици однедавно, али нису ушли у ширу употребу. Појам „акцент” паралелан је појму „stress” у енглеском, док би појам „ударение” представљао паралелу појму „асcеnt” (Лефельдт 2006: 13). У широј руској лингвистичкој литератури ова дихотомија није присутна, већ се најчешће, за акценат речи, користи термин „ударение”, односно „словесное ударение"2.

\section{Акценат као писани (графички) знак или својство изговорене речи \\ Други разлог за вишезначност термина „акценат” јесте и тај што се под њим подразумева „писани знак” изнад речи која се чита с једне}

${ }^{1}$ У новијим фонетикама савременог руског језика садржај појма акценат још је шири, односно дати појам се дефинише на следећи начин: „акценат је истицање у говору једне или друге јединице која се налази у низу истородних јединица, уз помоћ прозодијских средстава" (Князев и др. 2011: 157). Затим се наводе врсте акцента, у зависности од тога која јединица се истиче (чиме се подвлачи вишезначност датог термина): лексички (уколико се истиче слог), фразни или синтагматски (уколико се истиче једна, обично последња реч у синтагми) и логички (уколико се једна реч истиче по смислу).

2 у србистици не срећемо дату дихотомију. Ако бисмо повукли паралелу са сегментним јединицама - могли бисмо рећи да је ово пандан дихотомији „глас језика” и „глас говора”. Поставља се питање да ли је дихотомија „акцент” : „ударение” заиста неопходна и оправдана. Наш одговор на ово питање био би да она јесте оправдана, јер помоћу ње можемо врло једноставно одредити код којих речи се „својство” да имају акценат чешће, а код којих ређе реализује у конкретном говору (као „ударение”). Другим речима, врло лако је на овај начин одмах издвојити појмовне речи у односу на помоћне речи, одмах се јасно издвајају, на пример, у групи помоћних, проклитике, па се у међу њима лако могу изоловати оне проклитике које могу реализовати „ударение” (или како се данас често у фонетској литератури каже да се акценат „преноси на предлог или речцу” (Терзић 2003: 106). У српском би се реч „нагласак”, која се ређе употребљава, могла користити за тај надређени термин који акценат представља као апстрактно својство речи. 
стране, док се, с друге стране, под „акцентом” подразумева својство изговорене, односно „фонетске” речи.

\section{Тип акцента. Фонетски корелати руског акцента}

Руски акценат је квантитативан. Његова најизразитија особина јесте дужина. Акцентовани вокалски глас је дужи од свих осталих вокалских гласова у речи (уколико их, наравно има) ${ }^{3}$. Друга битна особина која издваја акцентовани вокалски глас независно од дужине (уколико је једносложна реч у питању) јесте квалитет, односно спектралне карактеристике акцентованог вокалског гласа (Кодзасов и др. 2001: 189). Квалитет вокалског гласа, његов спектар, различит је у зависности од тога је ли вокалски глас акцентован или не. Зато можемо рећи да је руски акценат квалитативно-квантитативан, рус. „качественно-количественное ударение" (Князев и др. 2005: 124).

Дуго се сматрало да је руски акценат динамички, односно, сматрало се да је доминантна објективна одлика руског акцента интензитет (субјективно „гласноћа”). После бројних експерименталних истраживања идеја о „динамичности" руског акцента почела је да се напушта већ педесетих година (видети експериментална истраживања Л. В. Златоустове (Златоустова 1953), да би била потпуно напуштена седамдесетих и осамдесетих година двадесетог века ${ }^{4}$. Интересантно је да се и много времена после експерименталних доказа о квантитативно-квалитативном карактеру руског акцента, многи врхунски лингвисти нису тако лако могли да напусте ову идеју: тако, на пример, И. С. Козирев и Л. П. Демиденко пишу да карактер руског акцента није најјаснији и да се са пуном сигурношћу може само рећи да руски акценат није мелодијски (Козырев и др. 1981: 57). У енциклопедији Языкознание (ур. В. А. Јарцева), у речничком чланку у вези с акцентом, В. А. Виноградов износи податак да у чистом виду квантитативни акценат није регистрован, док

${ }^{3}$ Када говоримо о дужини вокалског гласа, говоримо о његовој већој релативној дужини. Прво, акцентовани вокалски глас је дужи у односу на то када исти он није акцентован; друго, акцентовани вокалски глас је дужи у односу на просечно трајање вокалских гласова у речи. Већа релативна дужина акцентованог гласа јесте најпостојанија карактеристика акцентованог гласа, која важи за било који темпо говора, било који вокалски глас (Бондарко 1977: 154).

${ }^{4}$ М. И. Матусевич у свом уџбенику фонетике (Матусевич 1976: 223-225) издваја 4 релевантне особине акцентованог вокалског гласа: дужину, снагу, квалитет и висину. Иако свим особинама придаје, наизглед, једнаку пажњу, М. И. Матусевич ипак закључује: „У руском језику лексички акценат може се дефинисати на првом месту као кавлитативни, на другом - као квантитативни и на трећем као динамички" (Матусевич 1976: 225). 
је најважнија одлика руског акцента управо дужина (Виноградов 1998: 531). И највећи руски лингвисти тешко су се ослободили идеје о „динамичности" руског акцента. Тако Т. М. Николајева (Николаева 2008: 143) пише о томе како су лингвисти старије генерације дуго били у заблуди у погледу карактера руског акцента:

„Я вспоминаю сказанные мне слова А. А. Реформатского: «Вот, все говорят, что русское ударение выражается прежде всего длительностью, но как-то поверить в это полностью не могу. Конечно, оно экспираторно». Безусловно, вера в экспираторность русского ударения рождалась из дихотомии старых языковедческих предпосылок: ударение может быть музыкальным (тональным) или динамическим. Tertium non datur! Ho эксперимантальная фонетика с ее техническими возможностями развивается стремительно и потому было естественно, что лингвисты старших поколений еще долго жили в плену указанной дихотомии".

\section{Интензитет (субјективно „гласноћа”) акцентованог вокалског гласа у руском језику}

Док је идеја о динамичности руског акцента била прихваћена, лингвисти су утврдили да је, у неким случајевима, први предакцентовани вокалски глас могао да буде „гласнији” од акцентованог. Као пример

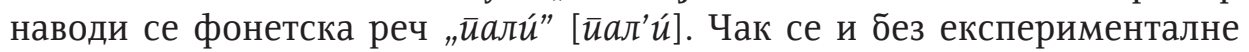
анализе, опажањем на слух, може уочити да је [а] из ове речи гласније од [иї] које је акцентовано. Објашњење (не потпуно тачно, како ће се касније испоставити), дао је Н. И. Жинкин (у Князев и др. 2005: 123): сваки акцентовани вокалски глас превазилази свој „праг гласноће”. Глас [иї] у речи „йали́” је превазишао свој „праг гласноће” („порог громкости"), док је глас [a] испод свог прага гласноће који досеже када је акцентован. Неважно је што је гласноћа [а] у односну на [иі̀] у датој речи већа. Међутим, даља истраживања су доказала да је вокалски глас из првог предакцентованог слога врло често гласнији, чак и ако је исти по тембру као акцентовани, односно у низовима [а]-[á], [и]-[ú], [y]-[ý] (Князев и др. 2005: 123; Панов 1979: 80). Ова релативна „гласноћа” се објашњава позицијом у речи, а не позицијом у односу на акцентовани глас: што је вокалски глас ближе почетку речи, већа је његова „гласноћа”. Место акцента са „гласноћом” нема везе (Златоустова и др. 1997: 286). Дешава се, додуше, да и данас, у новијој руској фонетској литератури, објашњење Н. И. Жинкина о „прагу гласноће” јесте једино, на пример, код Л. Л. Касаткина (Касаткин 2003: 66; ц: 63). 
У нашој новијој русистичкој лингвистичкој и методичкој литератури, руски акценат је и даље представљен као „динамички” (Терзић 2003: 100-1016; Пипер 2006: 107; Кончаревић 2004: 122), иако је о новијим истраживањима која руски акценат карактеришу као квантитативни, јер „је дужина <...> релевантнија од интензитета", писала Душанка Мирић још 1988. године (Мирић 1988: 36).

\section{Тип акцента. Фонетски корелати српског акцента}

Српски акценат је мелодијски (музички). Истицање једног слога, односно вокалског гласа (или сонанта [p]) у речи врши се покретом тона (узлазни или силазни покрет тона на вокалском гласу) и дужином (дуги или кратки акцентовани вокалски глас). Вокалски гласови после акцентованог могу бити дуги или кратки, у зависности од конкретне речи или облика речи, док су пре акцента сви вокалски гласови кратки. Овакав прозодијски систем српског језика је „први пут дефинитивно утемељен другом издању Вуковог Срйскоі̄ рјечника (1852) и серијом каснијих Даничићевих радова обједињених поводом стогодишњице његовог рођења (1925), <...>" (Петровић и др. 2010: 115). Српски четвороакценатски систем, могућност да једна реч у својој парадигми може „променити” сва четири акцента, присуство или одсуство постакценатских дужина чине српску акцентуацију врло тешком, а рекли бисмо и несавладивом за све који покушавају да науче комплетан „звучни отисак” било које српске речи. Акцентовани вокалски гласови у српском језику улазе у три типа контраста: а. по квантитету; б. по квалитету; в. по месту акцента (Петровић и др. 2010: 114-115; Пипер и др. 2013: 26).

Уколико сагледамо, узевши у обзир основне карактеристике које смо навели, обе врсте акцентуације (српску с аспекта руске и руску с аспекта српске), можемо закључити да су изворни говорници српског језика ипак у великој предности при учењу руског као страног у односу на матерње говорнике руског, приликом учења српског као страног, јер треба да савладају

${ }^{5}$ О оправдању термина „динамички” акценат с перцептивног аспекта (при прецепцији се дати слог издваја као најгласнији) пишу Л. В. Бондарко, Л. А. Васиљева и Л. М. Гордина (Бондарко и др. 2004: 121); с друге стране, пошто су узлазни покрети тона (на слогу који је носилац синтагматског акцента) интензивнији од покрета тона са силазним акцентом - у вези с узлазним покретом на акцентованом вокалском гласу оправдано је о руском акценту говорити као динамичком (Кодзасов 2009: 19).

${ }^{6}$ Наводе се и термини „динамичко-квантитативан”, „експираторан” и „експираторно-темпорални" акценат.

7 „Нагласак (...) није тонски него је ударно-квантитативни, (...).” 
само опозицију по месту акцента ${ }^{8}$ (што представља и највећу тешкоћу), док руски матерњи говорници савладавају опозиције по квантитету, квалитету и месту акцента за акцентовани вокаски глас.

\section{Акценатско језгро. Потебњина формула}

Како год било, можемо закључити да се у руској речи маркантно издвајају, највише својом дужином, први предакцентовани и акцентовани слог. Још је А. А. Потебња крајем XIX века описао карактеристичну ритмичку структуру речи, која је добила назив „Потебњина формула” (Князев и др. 2005: 124). Основна формула руске речи изгледа овако „112311”. Цифром „3” је обележен акцентовани вокалски глас, цифром „2" први предакцентовани глас, а цифром „1” - остали неакцентовани гласови. Први предакцентовани и акцентовани слог чине „акценатско језгро" сваке речи. Дато акценатско језгро се издваја у односу на остале слогове не само својом дужином, већ и различитом везом између предакцентованог и акцентованог слога, као и осталих слогова. Између првог предакцентованог и акцентованог слога постоји извесна пауза, како је приметио Н. И. Жинкин, док су неакцентовани слогови тешње повезани међу собом . (Федянина 1982: 15). У српском језику се не издваја акценатско језгро, нема кратке станке пред акцентованим вокалским гласом.

\section{Локализација акцента у речи руског језика. Неаутоматизовани (нефиксирани) акценат}

Руски језик припада језицима код којих се не може предвидети место акцента на основу фонетских законитости, какви су језици с такозваним „аутоматским” акцентом, у којима се прозодијска структура речи далеко лакше усваја. Аутоматски акценат је обично фискиран за почетак или крај речи и најједноставнији тип оваквог акцента представља такозвани „фиксирани” (или везани) акценат, какав имају чешки,

${ }^{8}$ Савладавјући дату опозицију у руском језику потребно је усвојити и пропратне појаве које она изазива: редукцију вокалских гласова, квалитет акцентованих гласова. Пошто постоје јасна правила у вези с пропратним појавама која су, можемо рећи, без изузетака, пред говорницима српског језика је далеко лакши задатак.

${ }^{9}$ Интересантно је да је ову карактерстику Н. И. Жинкин приметио још 1954. годи-

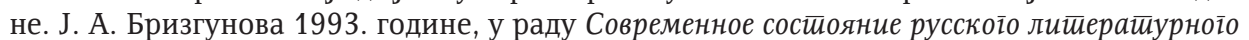

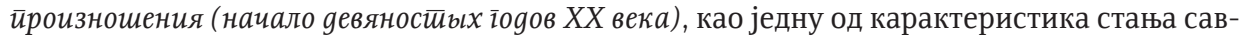
ременог руског изговора бележи и чињеницу да се „повећава дужина предакцентованих слогова, нарочито првог предакцентованог”, у оквиру ширих процеса које назива „појачавањем акања" и „ширењем икања" (Брызгунова 1993: 221). 
пољски или мађарски језик (Кодзасов и др. 2001: 479). Акценат руског језика припада неаутоматизованом нефиксираном акценту, или, како се он традиционално чешће назива, „слободном” акценту (Бондарко и др. 2004: 122). У језицима с везаним акцентом, сам акценат представља својство слога, док у језицима с невезаним акцентом као што је руски - акценат представља својство морфа (Курилович 1962: 76-77; Федянина 1982: 20). Лефелт развија већ познату тезу о „морфу као примарној јединици руске акцентологије” (Лефельдт 2006: 43-48). За именице су ти примарни акцентогени морфи, на пример, основа и флексија, како је показао још 1967. године А. А. Зализњак у књизи Русское именное словоизменение. У руском језику врло ретко су акцентовани префиксални и постфикслани морф, док су најчешћи морфи који су акцентовани коренски, суфиксални и флексиони (Зубкова 1985: 93-94).

\section{Покретни акценат}

Све би у руском језику било много лакше када би акценат речи, пошто се „смести” на одређени морф, на њему и остао у читавој парадигми речи. Када би овако у руском језику и било - усвајање места акцента не би било лако. Колико слогова - толико могућности за место акцента. И сама чињеница да не можемо на основу неких фонетских законитости предвидети место акцента у самој речи изазива довољну тешкоћу за учење руског језика за говорнике српског, па и не само српског језика, јер, како наводи Аванесов, место акцента у речи представља „индивидуалну карактеристику сваке конкретне речи” (Аванесов 1967: 11). Додатни проблем се огледа и у томе што акценат у парадигми речи често мења место, прелазећи с морфа на морф (најчешће с основе на флексију и обрнуто). Према овом свом својству, руски нефиксирани акценат зове се још и „покретни" („подвижное ударение”).

Огромна већина руских речи има постојан акценат било на основи или на флексији: према подацима Федјанине, чак $96 \%$ речи руског језика (Федянина 1982: 21), док покретни акценат има 720 именица, 376 придева и 294 глагола (Николаева 2008: 143). Управо ове речи, око 4 \% речи, чине основну, најфреквентнију лексику руског језика.

Из свега до сада реченог можемо закључити да реч не можемо научити, уколико не научимо и место акцента. Како би лакше класификовали све акцентуацијске моделе речи, руски лингвисти су их груписали у различите типове промене које се називају „акцентуацијским схемама” или „акценатским (акцентуацијским) парадигмама или кривама” („схема ударения”; „акцентная (акцентуационная) парадигма или кривая" (Феянина 1982: 22). У Грамайици савременої рускоі̄ књижевногі 
језика из 1970. године употребљен је термин „акцентная кривая” (Редькин 1970: 427). Именице су, рецимо, представљене као типови акцентних кривих $\mathrm{A}, \mathrm{B}, \mathrm{C}$ и D с подгрупама $\mathrm{A}_{1}, \mathrm{~B}_{1}, \mathrm{C}_{1}$ и $\mathrm{D}_{1}$ (Русская грамматика 1980: 432-442), док су код Федјанине (одакле их је преузео и кратко презентовао у свом уџбенику руске фонетике Л. Л. Касаткин (Касаткин 2003: 67-72) именичке парадигме описане као типови АА (акценат увек на основи), ВВ (акценат увек на наставку), АВ - у полупарадигми једнине акценат на основи, у полупарадигми множине акценат на наставку), ВА (наставак - основа), АС (једнина + номинатив множина акценат на основи, остали падежи множине - на наставку), ВС (једнина и множина - акценат на наставку, номинатив множине - на основи) СС - (акценат на наставку осим у акузативу једнине и номинативу множине). Дато је 10 типова именичких акцентуацијских парадигми (Федянина 1982: 38-39; 26-141).

\section{Акцентовани вокалски гласови}

Једнородност и неједнородност акцентованих вокалских гласова. „Гласные полного образования"

Акцентоване вокалске гласове називамо још и гласовима пуног образовања, рус. „гласные полного образования”, за разлику од редукованих гласова, о којима ће речи бити нешто ниже (рус. „редуцированные гласные").

Основних гласова је у српском 5 , а у руском $6^{10}$. Овај вишак у односу на српски представља вокалски глас [й́]. Сви вокалске гласове који се налазе у речи после тврдих сугласничких гласова најчешће су „једнородни"11. Разлике постоје и при изговору вокалских гласова, највише код [о] и [а] у односу на српски језик. Сваки акцентовани вокалски глас у руском језику варира у свом изговору у зависности од тога у каквој се сугласничкој околини нашао. Уколико је околина сугласничких гласова „тврда”, онда вокалски глас не трпи битне промене у односу на изоловани изговор. Међутим, уколико се акцентовани вокалски глас налази у мекој сугласничкој околини, онда он битно мења свој квалитет. Ова

${ }^{10}$ Нећемо улазити у домен фонологије: када говоримо о конкретном говорном гласу (самогласничком или сугласничком), увек мислимо на глас као „звукотип”, односно „еталон гласа”, („звук языка”), глас представљен у транскрипционим (квадратним) заградама, чијих тачних конкретних реализација има онолико, колико је говорника („звук речи”).

${ }^{11}$ осим гласа [о] који је неједнородан сам по себи, с призвуком гласа [у] у почетку артикулације и донекле [ы]. 
појава се у фонетској литератури најчешће назива „акомодацијом ${ }^{12 ”}$ вокалских гласова (Князев и др. 2005: 39-40), модификацијом (комбинаторне модификације у јакој позицији = акомодације) (Феоктистова 1985: 26) или, данас све чешће, „алтернацијом” вокалских гласова ${ }^{13} \mathrm{y}$ јакој позицији (Касаткин 2003:130-131). Акомодација вокалских гласова или алтернација вокалских гласова у јакој позицији одсусутвује у српском језику.

Иако можемо рећи да се готово ниједан глас руског језика не изговара као адекватан панадан вокалском гласу у руском језику, описаћемо разлике у артикулацији четири основна једнородна гласа, сматрајући да је артикулација гласова [и] и [у] веома слична ${ }^{14}$.

\section{Акцентовани глас [á] у руском језику у поређењу са српским}

На први поглед, имајући у виду описе руског и српског гласа [а], могли бисмо рећи да неке велике разлике нема. И руски и српски вокалски глас [а] класификују се као ниски вокали, средњег реда. Прва битна разлика на коју бисмо указали јесте неосетљивост српског [а] на фонетски контекст за разлику од руског [а]: српски глас „[а] (сем поменуте могућности назализирања) није осјетљив према фонетском контексту" (Симић и др. 1996: 175), док руски глас [а] итекако јесте осетљив на фонетски контекст: у суседству с предњојезичним тврдим сугласничким гласовима [т], [д], [c], [3], [н] „може бити окарактерисан као глас задњег реда, померен мало унапред ${ }^{15 " ~(Л ю б и м о в а ~ 1977: ~ 160), ~ д о к ~ с е ~ п о м е р а њ е ~}$

\footnotetext{
12 Против термина „акомодација”, односно описивања читаве појаве као „утицаја” сугласничких гласова на самогласничке, писао је М. В. Панов, покушавајући да укаже на његову негативну страну: „А что значит: влияет? не влияет? Ведь все это нельзя представить как процесс, как какое-то историческое воздействие: мы исследуем синхронное состояние языковой системы. Мягкий согласный влияет на конец гласного - это значит, что при последующем мягком согласном из трех вариаций: [а], [“a], [a'] - избирается [а'] - по законам языка, а не по прихоти говорящего" (Панов 1979: 150). Ми смо у потпуности сагласни с оваквим размишљањем М. В. Панова. Међутим, термин „акомодација” (као, уосталом, и термин „редукција”) је остао у широкој употреби, па га и ми у том смислу широко користимо у раду.

${ }^{13}$ Руски термин је „чередование гласных звуков”.

${ }^{14}$ Вокалске гласове руског и српског језика (еталоне гласова) акустички и артикулационо поредила је Душанка Мирић (Мирић 1988), поредивши ред и висину (према вредностима форманата) 5 вокалских фонема. Александар Белић за руске гласове [и] и [у] пише да су затворенији од српских (Белић 1968: 63; 65).

${ }^{15}$ Н. А. Љубимова вокалски глас [а] класификује као глас задњег реда, што срећемо и код Л. В. Бондарко (Бондарко 1977: 80), која, после обављеног експерименталног истраживања, пише: „йосле суїласничких їласова заgњеі̄ реgа вокалски іллас а се најмање

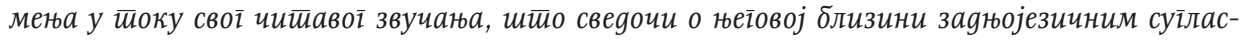
ничким іласовима". Већина фонетичара класификује глас [а] као вокал средњег реда (Акишина и др. 1990: 79; Панов 1979: 32; Касаткин 2003: 35; Князев и др. 2005: 38).
} 
језика уназад и његово подизање на границу меког и тврдог непца нарочито испољава после задњојезичних и [л]: (упоредити как, ax, лак, мал). Овај глас [а] можемо окарактерисати као вокал задњег реда (Любимова 1977: 160). Наравно, у позицији после назалних гласова и он добија елементе назализације. Можемо закључити да је руски глас [а] далеко више везан фонетским контекстом од српског гласа [а]. Интересантну разлику наводи и А. Терзић: „фонациона струја код руског [а] усмерава се углавном ка алвеолима и предњем непцу, код српског [а] се усмерава ка усном отвору" (Терзић 2003: 87).

Акцентовани глас [ó] у руском језику у поређењу са српским

Оба гласа, и српски глас [о] и руски, класификовани су као вокалски гласови средње висине, задњег реда. Најбитнија разлика између њих јесте у елементу лабијализације: у српском језику „језик је (код гласа $[0]-J . \Gamma$.) нешто више повучен уназад него код [а], а усне су мало истурене" (Симић и др. 1996: 177), док руски глас [о] има „дифтонгоидни карактер”, „[у]-образное начало” (Любимова 1977: 174; Стоева 2001: 68). Руски глас [о] је дифтонгоид, неједнородан глас, док је српски глас [о] једнородан глас. Пошто српски језик нема неједнородних вокалских гласова, у њему се ни не разликују термини „јеgнороgан-нејеgнороgан”, као у руском језику.

\section{Акцентовани глас [ь́́] у руском језику}

Глас [ы] одсуствује у српском језику. У руском је класификован као високи вокалски глас средњег реда, нешто нижи него гласови [и] и [у]. И дати глас има елемент дифтонгоидности. Најлакше се усваја када се изговара у позицији после задњојезично-задњонепчаних гласова. Код изговора гласова [к], [г] језик је померен уназад и налази се у позицији која је иста као код руског гласа [ы] (Любимова 1977: 172). Иако групе гласова [кы], [гы] нису карактеристичне за руски језик - неопходне су за лакше усвајање овог гласа.

Акцентовани глас [э́] у руском језику у поређењу са српским

Глас [э] је и у руском и у српском језику класификован као глас предњег реда, средње висине. Још је Александар Белић приметио да „руски језик има отвореније е од нашег (꿍) и затвореније (эти)” (Белић 1968: 64).

Сматрамо да управо у овом „реду” и лежи разлика: руски глас [а] је вокалски глас задњег реда, док је српски глас [а] вокалски глас средњег реда. 


\section{Неједнородност вокалских гласова. Дифтонгоди и полифтонгоиди}

Уколико се, на пример, с леве стране гласа [á] нађе мек сугласнички глас, као у речи „пя́тьй”, акцентовани вокалски глас постаје „неједнородан”, односно „дифтонгоидан”. У својој екскурзији он добија елемент гласа [и], што можемо представити овако: ["а]. Уколико би и с десне стране био мек сугласнички глас („nять”, дата неједнородност би била појачана и у рекурзији истог гласа, тако да дати глас има два елемента гласа [и] и постаје „полифтонгоидан”, што можемо представити овако: [" $\mathrm{a}^{\text {"] }}$ (Князев и др. 2005: 38). Л. Л. Касаткин визуелно представља неједнородност вокалског гласа на следећи начин: [•aì] у речи „иас”: [иэ-ӓ-а-а-а-а] (Касаткин 2003: 130). Почетна фаза (екскурзија) датог вокалског гласа померена је унапред и увис. Артикулационо и акустички овај глас, који ћемо у транскрипцији бележити [•á•], близак је одговарајућим нијансама гласа [•э́•] (Любимова 1977: 162), као у речи пе́ть.

Дата неједнородност није својствена акцентованим вокалским гласовима српског језика и на њу треба посебно обратити пажњу већ од почетака учења.

\section{Редуковани вокалски гласови}

\section{Редукција вокалских гласова као појава ${ }^{16}$. Квантитативна и квалитативна редукција}

За редукцију вокалских гласова, карактеристичну за руски језик, долази из најмање два разлога ${ }^{17}$ : прво, нефиксираност и покретност руског акцента, о којој смо говорили, омогућава да се створи „слаба тачка", односно отвори простор за потенцијалну редукцију. Други фактор који омогућава реализацију редукције јесте „централизујући” карактер („сильноцентрализующий характер”) руског акцента, који ствара следеће услове: акцентовани слог постаје веома изразит, самим тим и дужи по трајању, а сви остали слогови краћи (чиме се остварује квантитативна редукција) и мање напрегнути. С губитком напрегнутости вокалски

${ }^{16}$ Интересантно је и то да појам „редукција” М. В. Панов уопште не користи из истог разлога као ни појам акомодација, већ користи појам алтернација, или „чередование". Међутим, у руској фонетској литератури заиста су широко распрострањени појмови „гласные полного образования”, односно „самогласнички гласови пуног образовања” за акцентоване самогласничке гласове и „редуцированные гласные” за вокалске гласове који нису под акцентом (Федянина 1982: 16-7; Касаткин 2003: 133; Князев и др. 2005: 51-52), тако да их ни ми у раду нећемо избегавати.

${ }^{17}$ Наше претпоставке. 
гласови губе и свој спектар, чиме се остварује и квалитативна редукција. Редукција вокалских гласова је последица ове фузионе или „центрифугалне" силе која обезбеђује синтетичку структуру руске речи, чиме се у руском језику постиже неодвојивост компонената речи (Федянина 1982: 17).

Сви неакцентовани вокалски гласови руског језика мењају свој квантитет, односно постају краћи у односу на акцентовани вокалски глас. Оваква редукција се назива квантитативном (рус. „количественная редукция") и обухвата све гласове [и], [ы] и [у], [а], [э] и [o]. Други тип редукције је квалитативна редукција (рус. „качественная редукция”), која делује паралелно с квантитативном, обухвата гласове [а], [э] и [о]. у стандардном српском језику редукција гласова као појава одсуствује. Постоји појава која „све изразитије надире у стандардни језик, а тиче се редукције вокала у послеакцентованим положајима: $\bar{u} о с е \bar{u}^{u} л u, g o \bar{u}^{u} c н u \kappa$,

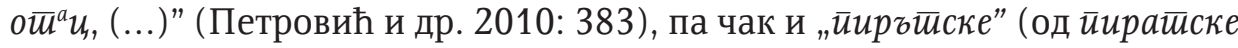
или $\bar{u} и р о \bar{u} с к е)$. Дате појаве се квалификују као нестандардне и нису у складу с ортоепском нормом (Петровић и др. 2010: 383-384).

Резултат редукције вокалских гласова као појаве јесте смањење броја вокалских гласова, па их, уместо 6 у основној позицији, (под акцентом) има само три или два (Касаткин 1999: 132). Дуго времена се сматрало су гласови [и], [ы] и [у] „имуни” по питању квалитативне редукције и да подлежу само квантитативној редукцији, односно да им се смањује само напрегнутост и дужина, али не и тембр. Квалитативну редукцију гласова [и], [ы] и [у] истраживачи су приписивали новијој појави која припада разговорном стилу. Утврђено је да и гласови [и], [ы] и [у] подлежу квалитативној редукцији: представник квалитативне редукције вокалских гласова после тврдих сугласничких јесте „нелабијализовано 'о'", у руској транскрипцији [ъ] или [ə], док је основни представник ре-

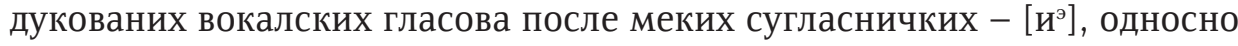
„редуковани вокалски глас предњег реда између “и' и 'е”” (Пауфошима 1980: 61; Панов 2002: 9) ${ }^{18}$.

Редукција гласова обухвата не само самогласнички глас, већ делује и на „спектралне карактеристике” сугласничких гласова читавог слога (Балихина 2010: 74), тако да ћемо, када говоримо о првом и другом степену редукције говорити о позицијама читавог слога ${ }^{19}$ у односу

${ }^{18}$ На основу смањења броја вокалских гласова у позицијама њихове редукције - можемо закључити да у савременом руском језику долази до смањења броја вокалских и повећања броја консонантских гласова, као и њихове дистинктивне снаге. Дати закон, који се шире посматра као фонетска тенденција развоја свих словенских језика (систем самогласничких фонема се смањује, систем сугласничких - повећава) М. В. Панов назвао је законом Бодуена де Куртенеа (Панов 1967: 336-337; Панов 2002: 87).

${ }^{19}$ Нећемо улазити у теорију слога, којих има више и које су врло компликоване. Сматрамо да теорија слога и не треба ни да припада настави прозодије у школском сис- 
на акцентовани слог. Најстабилније вокалске компоненте у речи чине гласови акцентованог, првог предакцентованог и последњег неакцентованог слога (Пауфошима 1980: 66).

Првом степену редукције, дакле, припадају први предакцентовани слог, сваки неприкривен слог (апсолутни почетак речи или вокалски глас после вокалског гласа унутар речи). Последњи отворен слог једни аутори третирају као позицију првог степена редукције (Реформатский 1999: 200), а други као позицију другог степена редукције (Сведения о произношении и ударении 1989: 647-648; Аванесов 1972: 62). Трећи, пак, сматрају, да се ова позиција апсолутног краја речи реализује или гласовима у првом или другом степену редукције (Касаткин 2003: 133). Неједнак третман дате позиције проистиче из разнородног понашања датог слога у зависности од тога да ли је употребљен у везаном говору или се налази пред паузом. С.В. Књазев и С. К. Пожарицка пишу да се последњи отворени слог може реализовати „гласовима у другом степену редукције (овај слог, у ствари, није апсолутни крај речи у везаном говору): [мамъ далаї]", док се пред паузом може реализовати истим гласом као у првом степену редукције (Князев и др. 2005: 53). Стога би се, по нашем мишљењу, у настави требало определити за други степен редукције, будући да су речи чешће унутар исказа него на самом његовом крају. Други степен редукције „покрива” већи број случајева, док на разлику између апсолутног краја речи пред паузом и у везаном говору треба указивати тек на студијама руског језика.

\section{Уместо закључка}

Датим радом смо се потрудили да осветлимо неке аспекте руског акцентуацијског система који су мање познати у нашој средини и о којима се мање или на други начин писало у нашој русистичкој литератури. Акцентуацији смо приступили као прозодијском средству чији су доминантни фонетски корелати у руском језику квантитет и квалитет акцентованог вокалског гласа, па се ова врста акцентуације назива квантитативно-квалитативном. До сада је у нашој русистичкој литератури преовладавало мишљење да је руска акцентуација динамичка. Навели смо аргументе који говоре у прилог тези који руску акцентуацију квалификују као квантитативно-квалитативу, а не динамичку. Наводе се и аргументи у прилог нединамичности руске акцентуације. Основни

тему, иако слог јесте прозодијска јединица. Носилац слога увек је вокалски глас у руском језику. С друге стране, установљено је да у највећем броју комбинација сугласничких и самогласничких гласова у руском језику - граница иде испред дате комбинације, „у вези с чим је унутрашњи („неконечный слог”) обично отворен” (Князев 2006: 16). 
фонетски корелат српске акцентуације је мелодија, уз важну улогу дужине и места акцента у речи. Акцентуацији смо приступили и из угла прозодијских јединица, односно, вокалских гласова, акцентованих и редукованих. Најважније особине акцентованих вокалских гласова руског језика смо набројали (једнородност/неједнородност односно дифтонгоидност и полифтонгоидност акцентованих вокалских гласова, издвајање прозодијског језгра), упоредивши их с акцентованим вокалима српског језика. Неакцентовани вокали руског језика подлежу редукцији, о чему смо такође писали из угла квантитативне и квалитативне редукције (чак и високих вокала), упоредивши дате особине са савременим српским језиком.

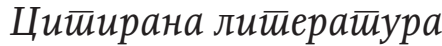

Аванесов, Рубен И. Русское литературное произношение. Москва: Просвещение, 1967.

Аванесов, Рубен И. Русское литературное произношение. Москва: Просвещение, 1972.

Акишина, Алла А., Светлана А. Барановская. Русская фонетика. Москва: Русский язык, 1990.

Балыхина, Татьяна М. Методика преподавания русского языка как неродного (нового). Учебное пособие. Москва: Российский университет дружбы народов, 2010.

Белић, Александар. Савремени српскохрватски књижевни језик. Први део: Гласови и акценат. Београд: Научна књига, 1968.

Бондарко, Лилия В., Людмила А. Вербицкая, Мирра В. Гордина. Основы общей фонетики. Санкт-Петербург: Издательский центр «Академия», 2004.

Бондарко, Лилия В. Звуковой строй современного русского языка. Москва: Просвещение, 1977.

Брызгунова, Елена А. «Современное состояние русского литературного произношения (начало девяностых годов XX века)». Зборник Матице српске за славистику, 44-45, 1993: 221-225.

Виноградов, Виктор А. «Ударение» [В]: В. Н. Ярцева (ред.) Языкознание. Большой энциклопедоческий словарь. Москва: Большая российская энциклопедия, 1998, 531-532.

Златоустова, Любовь В. Фонетическая природа русского словесного ударения (на основе экспериментальных данных). Автореферат кандидатской диссертации. Ленинград, 1953.

Златоустова, Любовь В., Родмонга К. Потапова, Всеволод В. Потапов, Валериан Н. Трунин-Донской. Общая и прикладная фонетика. Учебное пособие. Москва: Издательство МГУ, 1997.

Зуббкова, Людмила Г. «Синтагматические отношения в фонетической системе русского языка» [В]: Л. А. Новиков (ред.) Современный русский язык. Теоретический курс. Фонетика. Москва: Русский язык, 1985: 67-111. 
Касаткин, Леонид Л. Современная русская диалектная и литературная фонетика как источник для истории русского языка. Москва: Наука; Школа «Языки русской культуры», 1999.

Касаткин, Леонид Л., Фонетика современного русского языка. Москва: МГУ, 2003.

Князев, Сергей В., Софья К. Пожарицкая. Современный русский литературный язык. Фонетика, графика, орфография, орфоэпия. Москва: Академический Проект, Гаудеамус, 2011.

Князев, Сергей В., Софья К. Пожарицкая. Современный русский литературный язык. Фонетика, графика, орфография, орфоэпия. Москва: Академический Проект, 2005.

Князев Сергей В. Структура фонетического слова в русском языке: синхрония и диахрония. Москва: Макс-Пресс, 2006.

Кодзасов, Сандро В. Исследования в области русской просодии. Москва: Языки славянских культур, 2009.

Кодзасов, Сандро В., Ольга Ф. Кривнова. Общая фонетика. Москва: Российский государственный гуманитарный университет, 2001.

Козырев, Иван С, Лариса П. Демиденко. Современный русский язык. Фонетика. Орфоэпия. Минск: Вышэйшая школа, 1981.

Кончаревић, Ксенија. Савремена настава руског језика. Садржаји. Организација. Облици. Београд: Славистичко друштво Србије, 2004.

Курилович, Ежи. «Структура морфемы». [В]: Очерки по лингвистике. Сборник статей. Москва: Иностранная литература, 1962: 71-91.

Лефельдт, Вернер. Акцент и ударение в русском языке. Москва: Языки славянской культуры, 2006.

Любимова, Нина А. Обучение русскому произношению. Артикуляция. Постановка и коррекция русских звуков. Москва: Русский язык, 1977.

Матусевич, Маргарита И. Современный русский язык. Фонетика. Москва: Просвещение, 1976.

Мирић, Душанка. «Карактеристике руског и српскохрватског вокалског подсистема у контакту». Живи језици ХХX, 1-4, 1988: 28-40.

Николаева, Татьяна М. В. Лефельдт. Акцент и ударение в русском языке. М.: Языки славянской культуры, 2006. Вопросы языкознания 2, 2008: 142-146.

Панов, Михаил В. Русская фонетика. Москва: Просвещение, 1967.

Панов, Михаил В. Современный русский язык. Фонетика. Москва: Высшая школа, 1979.

Панов, Михаил В. Из истории русского литературного произношения. XVIII-XX вв. Москва: Едиториал УРСС, 2002.

Пауфошима, Розалия Ф. «Об использовании регистровых различий в русской фразовой интонации (на материале русского литературного языка и севернорусских говоров». [В:] А. А. Зализняк (ред.) Славянское и балканское языкознание. Просодия. Сборник статей. Москва: Наука, 1989: 53-64.

Петровић, Драгољуб, Снежана Гудурић. Фонологија српскога језика. Београд: Институт за српски језик САНУ, Београдска књига, Матица српска, 2010. 


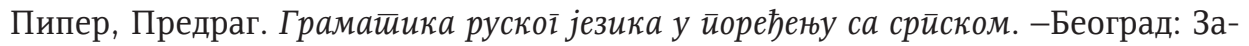
вет, 2006.

Пипер, Предраг, Иван Клајн. Нормативна граматика српског језика. Нови Сад: Матица српска, 2013.

Реформатский, Александр А. Введение в языковедение, Москва: Наука, 1999.

Русская грамматика. Том I. Фонетика. Фонология. Ударение. Интонация. Словообразование. Морфология. Москва: Наука, 1980.

Сведения о произношении и ударении. [В:] Р. А. Аванесов (ред.) Орфоэпический словарь русского языка. Произношение, ударение, грамматические формы. Москва: Русский язык 1989: 642-685.

Симић, Радоје, Бранислав Остојић. Основи фонологије српског књижевног језика. Београд: Универзитет у Београду, 1996.

Стоева, Тотка. Русская фонетика. Очерк русской сегментной и суперсегментной фонетики в сравнении с болгарской. София: Университетское издательство им. Св. Климента Охридского, 2001.

Терзић, Александар. Фонетика руског језика. Београд: Славистичко друштво Србије, 2003.

Федянина, Нина А. Ударение в современном русском языке. Москва: Русский язык, 1982.

Феоктистова, Алевтина С. «Звуковой строй русского языка». [В] Современный русский язык. Теоретический курс. Фонетика. Москва: Русский язык, 1985: 9-29.

Gut, Ulrike, Juergen Trouvain, William Barry. «Bridging research on phonetic descriptions with knowledge from teaching practice - The case of prosody in non-native speech». [In:] Non-Native Prosody. Phonetic Description and Teaching Practice. Berlin; New York: Mouton de Gruyter, 2006: 3-21.

\section{Елена Гинич}

РУССКАЯ И СЕРБКАЯ АКЦЕНТУАЦИЯ В КОНТРАСТЕ

\section{Резюме}

В данном докладе мы постарались рассмотреть некоторые аспекты русской акцентуационной системы не очень известные в сербской среде, о которых мало писали или их по-другому трактовали в домашней литературе по русистике. Акцентуацию русского языка, словесное ударение, мы рассматривали как просодическое средство, основным фонетическим коррелятом которого является количество и качество ударного гласного. Поэтому русское словесное ударение называется качественно-количественным. До сих пор в нашей литературе по русистике преобладало мнение, что русскоге словесное ударение является 
динамическим. Мы привели аргументы в пользу тезиса, которые подтверждают, что основным фонетическим коррелятом русского ударения являются качество и количество ударного гласного. Мы привели и аргументы в пользу нединамичности русского ударения. Основным коррелятом сербского ударения является мелодия, наряду с количеством и местом ударения. Когда писали об акцентуационных системах двух языков, мы писали и о просодических единицах - ударных и редуцированных гласных русского языка. Мы перечислили самые важные особенности ударных гласных русского языка (однородность/ неоднородность ударных гласных, дифтонгоидность, полифтонгоидность, выделение просодического ядра), сравнив данные особенности с ударными гласными сербского языка. Безударные гласные русского языка редуцируются, о чём мы писали, имея в виду количественную и качественную редукцию (даже гласных верхнего подъёма), сравнив данные особенности с особенностями безударных гласных современного сербского языка.

Ключевые слова: акцент, ударение, гласный звук, количественно-качественное ударение, музыкальное ударение, однородность, неоднородность, редукция, место ударения 